\title{
OCENA WIEDZY PIELĘGNIAREK ŚRODOWISKOWYCH DOTYCZACEEJ PROFILAKTYKI CHORÓB NOWOTWOROWYCH
}

\author{
ASSESSMENT OF KNOWLEDGE REGARDING CANCER PREVENTION AMONG COMMUNITY \\ NURSES
}

Krzysztof Adamowicz

Szpital Specjalistyczny w Wejherowie

DOI: https://doi.org/10.20883/pielpol.2017.51

\section{STRESZCZENIE}

Wstęp. Choroby nowotworowe w krajach rozwiniętych stanowią drugą w kolejności przyczynę zgonów. Podobnie jak na całym świecie, w Polsce wzrost zachorowań na nowotwory przypisywany jest starzeniu się społeczeństwa i zwiększającej się ekspozycji na rakotwórcze czynniki środowiskowe. Pielęgniarka środowiskowa może zwracać uwagę na pierwsze objawy choroby nowotworowej, ale wymaga to właściwej wiedzy onkologicznej. Rolą pielęgniarki powinno być też edukowanie pacjentów w zakresie dostępnych w Polsce programów badań przesiewowych i prewencji nowotworów oraz nakłanianie do prozdrowotnych modyfikacji stylu życia.

Cel. Celem pracy była ocena wiedzy pielęgniarek środowiskowych na temat nowotworów, znajomości podstawowych zasad edukacji onkologicznej i wpływu stylu życia na zachorowania nowotworowe oraz realizowanych w Polsce programów profilaktycznych z zakresu chorób nowotworowych.

Materiał i metody. Badaniem objęto łącznie 70 pielęgniarek środowiskowych/rodzinnych. Oceniono wiedzę pielęgniarek o nowotworach i roli badań przesiewowych oraz prewencji chorób nowotworowych. Dodatkowo uwzględniono informacje o zachowaniach prozdrowotnych wśród badanych.

Wyniki. Ogólny poziom wiedzy był niski. Wprawdzie za najbardziej szkodliwe uznawały pielęgniarki palenie tytoniu, promieniowanie ultrafioletowe oraz otyłość i brak aktywności fizycznej, to jednak w większości ankietowane uznawały, że modyfikacja zachowań nie doprowadzi do zmniejszenia ryzyka zachorowania na choroby nowotworowe. Ponadto wiedza na temat programów profilaktyki chorób nowotworowych była niewystarczająca. Znaleziono związek pomiędzy poziomem wiedzy onkologicznej a prozdrowotnością stylu życia ankietowanych pielęgniarek. Podsumowanie. Wydaje się, że tylko właściwie przeprowadzony program edukacji w zakresie chorób nowotworowych, obejmujący wszystkie pielęgniarki, przed wyborem zakresu dalszej edukacji mógłby poprawić zaistniałą sytuację. W opinii autora program taki powinien być ciągły i w swoim przebiegu uwzględniać specyfikę pracy pielęgniarek środowiskowych.

SŁOWA KLUCZOWE: rak, wiedza o chorobach nowotworowych, pielęgniarka.

\section{ABSTRACT}

Introduction. Cancer diseases are the second cause of death in developed countries. Like all over the world, in Poland, an escalation in the incidence of cancer is attributed to the aging population and increasing exposure to carcinogenic environmental factors. The community nurse can pay attention to the first symptoms of cancer, but it requires proper knowledge of oncology. The role of nurses should also be educating patients in terms of available screening programs and prevention of cancer, as well as advocating the healthy lifestyle in Poland.

Aim. The aim of the study was to assess knowledge concerning cancer, awareness of the basic principles of oncology education and the influence of the lifestyle on the cancer onset and implemented prevention programs in the field of cancer among community nurses in Poland.

Material and methods. The study included a total of $70 \mathrm{commu}-$ nity nurses/ family nurses. The knowledge of nurses about cancer and the role of screening and prevention of cancer have been rated. Additionally, information about healthy behaviors among respondents has been considered.

Results. The overall level of knowledge was low. Even though nurses recognize smoking, ultraviolet radiation, obesity and lack of physical activity as the most harmful behaviors, the majority of respondents claim that the modification of behavior will not lead to a reduction in the risk of cancer. In addition, knowledge of cancer prevention programs was insufficient. However, a statistically significant relationship was found between the level of knowledge of cancer and the health-promoting lifestyle of the surveyed nurses.

Summary. It seems that the only properly conducted education program in the field of cancer, including all the nurses, before selecting the precise field of education could improve the present situation. In the author's opinion, such a program should be continuous and take into account the specific nature of community nurses' work.

KEYWORDS: cancer, knowledge of cancer diseases, nurse. 


\section{Wstęp}

Choroby nowotworowe stanowią drugą w kolejności, po chorobach układu sercowo-naczyniowego, przyczynę zgonów w krajach rozwiniętych. Istnieją dwie główne grupy czynników mających związek z rozwojem chorób nowotworowych: środowiskowe i genetyczne. Najważniejsze to czynniki środowiskowe, w tym przede wszystkim niewłaściwy styl życia [1]. O ile jednak nie można zmienić czynników genetycznych, to istnieje szansa eliminacji niekorzystnych czynników związanych z trybem życia poprzez ukierunkowanie myślenia ludzi na rzecz prozdrowotnego stylu życia.

Zmniejszenie śmiertelności z powodu chorób nowotworowych wymaga integracji działań profilaktycznych, organizacyjnych i leczniczych. Zgodnie z obecnie rozwijanym modelem służby zdrowia podstawowymi realizatorami strategicznych założeń profilaktyki onkologicznej Narodowego programu zwalczania chorób nowotworowych na poziomie pojedynczego pacjenta powinni być lekarze pierwszego kontaktu oraz pielęgniarki środowiskowe i pielęgniarki podstawowej opieki zdrowotnej. Aktywne słuchanie, udzielanie informacji i pomocy w rozwiązywaniu problemów związanych z chorobą nowotworową i leczeniem stanowią o pełnej roli pielęgniarki i niejednokrotnie decydują o przebiegu leczenia oraz rehabilitacji.

Zgodnie z wytycznymi Narodowego Funduszu Zdrowia (NFZ) pielęgniarka środowiskowa lub rodzinna powinna w ramach swoich świadczeń w zakresie promocji zdrowia i profilaktyki realizować następujące cele:

- rozpoznawanie, ocena i zapobieganie zagrożeniom zdrowotnym,

- rozpoznawanie potrzeb pielęgnacyjnych i problemów zdrowotnych,

- $\quad$ prowadzenie edukacji zdrowotnej, w tym dokonywanie oceny poziomu wiedzy, umiejętności i motywacji do zachowań prozdrowotnych,

- $\quad$ prowadzenie poradnictwa w zakresie zdrowego stylu życia,

- $\quad$ realizacja programów promocji zdrowia i profilaktyki chorób,

- organizacja grup wsparcia,

- realizacja szczepień ochronnych,

- $\quad$ prowadzenie działań profilaktycznych u grup ryzyka zdrowotnego [2].

Profilaktyka chorób nowotworowych realizuje się we wszystkich wyżej wymienionych punktach. Bez właściwej wiedzy onkologicznej pielęgniarka środowiskowa nie jest w stanie rozpoznawać objawów choroby nowotworowej oraz edukować chorych.

Profilaktyka nowotworów to również dążenie do rozpoznania choroby w stadium możliwie jak najwcześniej- szym, przy uwzględnieniu efektywności ekonomicznej badań profilaktycznych. Zgodnie z tymi założeniami prowadzenie zakrojonych na szeroką skalę badań profilaktycznych w onkologii jest uzasadnione wówczas, gdy badanie pozwalające na wykrycie choroby jest łatwo dostępne i relatywnie tanie, a wczesne wykrycie choroby prowadzi do poprawy wyników leczenia. Kierując się tymi kryteriami, przyjęto, że nowotworami, w których badania przesiewowe mają uzasadnienie, są: rak piersi, rak szyjki macicy i rak jelita grubego. Jednak realizacja badań przesiewowych w Polsce jest zła [3]. Największą zgłaszalność na badania profilaktyczne (do 39\%) osiągnięto w 2007 roku, kiedy zorganizowano kampanię medialną, wysyłano zaproszenia, a darmowe mammografie były zapewniane nawet w mammobusach, które docierały bezpośrednio do małych miejscowości [3]. Z danych Wojewódzkiego Centrum Onkologii w Gdańsku wynika, że na wysłane 11960 zaproszeń zgłosiło się zaledwie 2701 kobiet. W naszym kraju zgłaszalność na badania cytologiczne w ramach profilaktyki raka szyjki macicy jest jedną z najniższych w Europie i nie przekracza 15\% [4]. Wprawdzie rośnie liczba wykonywanych badań, to jednak zainteresowanie badaniami profilaktycznymi ciągle jest niskie w porównaniu z krajami Europy Zachodniej. Można zakładać, że niska zgłaszalność uwarunkowana jest brakiem informacji o realizacji badań profilaktycznych. Natomiast właściwie wyedukowana pielęgniarka środowiskowa mogłaby przekazać wiedzę o możliwości wykonania badania przesiewowego oraz o dostępności takiego badania. Zatem rolą pielęgniarki powinno być także edukowanie pacjentów w zakresie dostępnych w Polsce programów badań przesiewowych.

Prozdrowotny styl życia (inaczej zachowania prozdrowotne) definiowany jest współcześnie jako te formy aktywności człowieka, które są przyczyną utrzymania, umacniania i przywracania zdrowia [5]. Szacuje się, że około $70 \%$ nowotworów złośliwych jest następstwem działania szkodliwych czynników związanych ze stylem życia i dietą lub innych czynników występujących w otaczającym środowisku [1]. Do prowadzenia poradnictwa w zakresie zdrowego stylu życia pielęgniarka pełniąca funkcję edukatora powinna posiadać wiedzę na temat wpływu stylu życia na stan zdrowia. Wartościowe byłoby także, aby sama realizowała zachowania prozdrowotne.

Podane wyżej argumenty wraz z danymi sugerującymi, że nowotworom można zapobiegać poprzez modyfikację swojego stylu życia, przekonują o niezwykle wysokiej randze wiedzy o prewencji zachorowań na nowotwory. Powyższe dane przekonują też o potencjalnej roli edukacji zdrowotnej w zakresie prewencji chorób nowotworowych. Zaś punktem wyjścia właściwej edukacji jest ocena obecnej wiedzy onkologicznej 
personelu medycznego. Z tego względu podjęto próbę oceny stanu wiedzy pielęgniarek środowiskowych w zakresie profilaktyki chorób nowotworowych oraz ich zachowań prozdrowotnych.

\section{Materiał i metody}

Badaniem objęto 70 pielęgniarek środowiskowych i rodzinnych z województwa pomorskiego. Do badania włączano pielęgniarki, które zgłosiły się na cykl wykładów dotyczących prewencji chorób nowotworowych; pielęgniarki zostały poproszone o wypełnienie ankiet przed wykładami. Wykluczano osoby leczone z powodu choroby nowotworowej, gdyż założono, że przeszły one dodatkową edukację w związku z przebytą lub bezpośrednio zagrażającą chorobą nowotworową. Podczas badań wykorzystano metodę sondażu diagnostycznego opartego na dwóch anonimowych kwestionariuszach, a warunkiem przeprowadzenia badania była dobrowolna i świadoma zgoda badanej. Pierwszy kwestionariusz był własnej konstrukcji. Składał się z 39 pytań podzielonych na trzy grupy tematyczne: styl życia i jego modyfikacje, programy badań profilaktycznych, ogólna wiedza onkologiczna. Dodatkowo poszukiwano związku pomiędzy wiekiem, wykształceniem a wiedzą onkologiczną. Do celów szczegółowych należało też określenie dziedziny, w której wiedza onkologiczna ankietowanych pielęgniarek jest największa i najmniejsza, tak by powstały w przyszłości program szkoleń obejmował odpowiednie zagadnienia. Drugim z zastosowanych kwestionariuszy był kwestionariusz IZZ (Inwentarz Zachowań Zdrowotnych) autorstwa prof. Z. Juczyńskiego określający nasilenie zachowań prozdrowotnych i stylu życia. Ankieta składa się z 24 pytań zamkniętych i 1 pytania otwartego. Biorąc pod uwagę wskazaną przez badane częstotliwość poszczególnych zachowań, ustalono nasilenie zachowań sprzyjających zdrowiu oraz stopień nasilenia czterech kategorii zachowań zdrowotnych, tj. prawidłowych nawyków żywieniowych, zachowań profilaktycznych, praktyk zdrowotnych, pozytywnego nastawienia psychicznego. Zgodnie z zaleceniami autora ankiety wyniki w zakresie 1-4 stena oceniono jako niskie, 5 i 6 stena - jako przeciętne, a 7-10 stena - jako wysokie [5]. Wyniki uzyskane przez pielęgniarki zestawiono z wynikami uzyskanymi od osób zdrowych zgłaszających się w tym czasie do lekarza podstawowej opieki zdrowotnej w celach administracyjnych. Była to grupa 50 osób dobranych pod względem płci i wieku do analizowanej grupy badanej. W analizie wyników zastosowano podstawowe statystyki opisowe. Średnie arytmetyczne porównywano testem t-Studenta w przypadku dwóch zmiennych i na podstawie analizy ANOVA dla więcej niż dwóch zmiennych. W ocenie związku pomiędzy wiedzą onkologiczną a stylem życia zastosowano regresję logistyczną (wiek, płeć, wykształcenie, wywiad rodzinny, palenie tytoniu). Wartość p poniżej 0,05 uznano za statystycznie istotną. Do obliczeń statystycznych wykorzystano program Excel firmy Microsoft w wersji 2003 oraz program PQSTAT w wersji 1.4. Bazy danych przedstawiono z zachowaniem pełnej anonimowości.

\section{Wyniki}

Spośród wręczonych 70 kwestionariuszy otrzymano zwrotnie 68 odpowiedzi, co dało wskaźnik odpowiedzi równy $97,1 \%$. Ponadto jedna ankieta została wykluczona z analizy z powodu nieprawidłowości w udzielonych odpowiedziach uniemożliwiających ich analizę. Błędy polegały na wpisaniu słów: „nie wiem” i zaznaczeniu kilku odpowiedzi w jednym pytaniu. Charakterystykę badanych pielęgniarek przedstawiono w tabeli 1.

Tabela 1. Charakterystyka badanej populacji

Table 1. Characteristics of the study population

\begin{tabular}{ccc}
\hline $\begin{array}{c}\text { Charakterystyka/ } \\
\text { Characteristic }\end{array}$ & $\begin{array}{c}\text { Liczba/ } \\
\text { Number }\end{array}$ & $\begin{array}{c}\text { Procent/ } \\
\text { Percentage }\end{array}$ \\
\hline Wykształcenie/Education & & \\
wyższe/higher education & 17 & 25,4 \\
średnie/secondary education & 50 & 74,6 \\
Miejsce zamieszkania/Place of residence & & \\
$\quad$ miasto/city & 40 & 59,7 \\
$\quad$ wieś/village & 27 & 40,3 \\
Wykształcenie rodziców/Education of parents & & \\
• ojca/father & & \\
wyższe/higher education & 16 & 23,9 \\
średnie/secondary education & 27 & 40,3 \\
niższe/vocational education & 24 & 35,8 \\
• matki/mother & & \\
wyższe/higher education & 14 & 20,9 \\
średnie/secondary education & 25 & 37,3 \\
niższe/vocational education & 28 & 41,8 \\
\hline
\end{tabular}

Źródło: opracowanie własne

Source: author's own analysis

\section{Wiedza onkologiczna pielęgniarek}

Średnia wartość uzyskana w ankiecie to 83 (zakres 68-103) pkt. Mediana wyniosła 84 pkt. Odchylenie standardowe było równe 6,96 pkt. Najwyższy wynik (103 pkt) uzyskany został przez 47-letnią pielęgniarkę z wyższym wykształceniem, mieszkankę Wejherowa, której rodzice mieli wyższe wykształcenie. Najniższy wynik to 68 pkt. Uzyskała go 26-letnia mieszkanka wsi, której rodzice posiadali wykształcenie podstawowe, ona zaś miała średnie wykształcenie. Wyniki zestawiono w tabeli 2. Średnia wieku ankietowanych pielęgniarek wyniosła 39 lat. 
Tabela 2. Wyniki ankiety dotyczącej wiedzy onkologicznej Table 2. The results of a survey (knowledge of cancer)

\begin{tabular}{ccc}
\hline $\begin{array}{c}\text { Poziom wiedzy/ } \\
\text { Group-level of knowledge }\end{array}$ & $\begin{array}{c}\text { Liczebność/ } \\
\text { Number }\end{array}$ & $\begin{array}{c}\text { Procent/ } \\
\text { Percentage }\end{array}$ \\
\hline Niski/Low & 17 & 25,4 \\
Średni/Average & 21 & 31,3 \\
Dość wysoki/Above the average & 19 & 28,4 \\
Wysoki/High & 10 & 14,9 \\
\hline
\end{tabular}

Źródło: opracowanie własne

Source: author's own analysis

Najmłodsza ankietowana miała 25 lat, najstarsza 64 lata. Szczegółowe wyniki dla poszczególnych grup wiekowych przedstawiono w tabeli 3.

Tabela 3. Wyniki grupy badanej w zestawieniu z wartościami uzyskanymi przez grupę kontrolną i wynikami normalizacji

Table 3. The results of the study group in comparison with the values of the control group and the standardization

\begin{tabular}{|c|c|c|c|}
\hline \multicolumn{4}{|c|}{$\begin{array}{l}\text { Wiedza onkologiczna/ } \\
\text { Knowledge of cancer }\end{array}$} \\
\hline $\begin{array}{c}\text { Cecha/ } \\
\text { Characteristic }\end{array}$ & $\begin{array}{l}\text { Średnia wartość/ } \\
\text { Mean score } \\
\text { grupa badana/ } \\
\text { research group }\end{array}$ & $\begin{array}{l}\text { Średnia wartość/ } \\
\text { Mean score } \\
\text { grupa kontrolna/ } \\
\text { control group }\end{array}$ & $\begin{array}{l}\text { Normalizacja/ } \\
\text { Normalization }\end{array}$ \\
\hline $\begin{array}{c}\text { Wiek/Age } \\
\text { poniżej31. roku życia/below31 } \\
\text { od } 31 \text { do } 40 \text { lat/31 to } 40 \\
\text { od } 41 \text { do } 50 \text { lat/41 to } 50 \\
\text { powyżej } 50 \text {. roku życia/over } 50\end{array}$ & $\begin{array}{l}80 \mathrm{pkt} \\
85 \mathrm{pkt} \\
91 \mathrm{pkt} \\
82 \mathrm{pkt}\end{array}$ & $\begin{array}{l}68 \mathrm{pkt} \\
72 \mathrm{pkt} \\
76 \mathrm{pkt} \\
71 \mathrm{pkt}\end{array}$ & $72 \mathrm{pkt}$ \\
\hline $\begin{array}{l}\text { Wykształcenie/Education } \\
\text { średnie/secondary education } \\
\text { wyższe/high education }\end{array}$ & $\begin{array}{l}83 \mathrm{pkt} \\
87 \mathrm{pkt}\end{array}$ & $\begin{array}{l}71 \mathrm{pkt} \\
73 \mathrm{pkt}\end{array}$ & $72 \mathrm{pkt}$ \\
\hline \multicolumn{4}{|c|}{$\begin{array}{l}\text { Inwentarz Zachowań Zdrowotnych/ } \\
\text { Inventory of Behavioral Health }\end{array}$} \\
\hline $\begin{array}{l}\text { Prawidłowe nawyki żywie- } \\
\text { niowe/Proper eating habits }\end{array}$ & $3,09 \mathrm{pkt}$ & $2,98 \mathrm{pkt}$ & $3,60 \mathrm{pkt}$ \\
\hline $\begin{array}{l}\text { Zachowania profilaktycz- } \\
\text { ne/ Preventive behaviors }\end{array}$ & $3,22 \mathrm{pkt}$ & $3,02 \mathrm{pkt}$ & $3,48 \mathrm{pkt}$ \\
\hline $\begin{array}{l}\text { Pozytywne nastawienie } \\
\text { psychiczne/Positive } \\
\text { mental attitude }\end{array}$ & $3,51 \mathrm{pkt}$ & $3,30 \mathrm{pkt}$ & $3,74 \mathrm{pkt}$ \\
\hline $\begin{array}{l}\text { Praktyki zdrowotne/ } \\
\text { Health practices }\end{array}$ & 3,33 pkt & $3,09 \mathrm{pkt}$ & $3,53 \mathrm{pkt}$ \\
\hline
\end{tabular}

Źródło: opracowanie własne

Source: author's own analysis

Ogólny wynik grupy badanej był wyższy niż wynik standaryzowany, który wynosi 72 pkt $(p<0,01)$. Grupa kontrolna (50 osób dobranych pod względem płci i wieku do analizowanej grupy badanej) uzyskała istotnie niższy średni wynik od ankietowanych pielęgniarek (72 pkt; $p<0,01)$, ale podobny do wyniku standaryzowanego $(p=0,71)$.

Nie znaleziono statystycznie istotnego związku pomiędzy wiekiem a wiedzą ankietowanych pielęgniarek $(p=0,83)$. Nie stwierdzono także różnic statystycznie znamiennych w zakresie wiedzy onkologicznej po- między pielęgniarkami z wykształceniem wyższym i średnim ( $p=0,67$; średnia wartość punktowa wyniosła odpowiednio 87 i 84 pkt; tabela 3). Na poziom wiedzy onkologicznej nie miało także wpływu wykształcenie matki ankietowanych $(p=0,69)$, wykształcenie ojca $(p=0,88)$, a także miejsce zamieszkania $(p=0,82)$. Ocena tematyczna pytań wykazała, że średnia wartość punktowa odpowiedzi na pytania dotyczące stylu życia i jego modyfikacji była wyższa do średniej wartości odpowiedzi na pytania z zakresu ogólnej wiedzy onkologicznej $(p<0,01)$ i z programów badań profilaktycznych $(p<0,01)$. Wiedza w zakresie programów badań profilaktycznych oraz ogólna wiedza onkologiczna również nie różniły się istotnie $(p=0,27)$.

\section{Inwentarz Zachowań Zdrowotnych}

Wskaźnik nasilenia zachowań zdrowotnych w badanej populacji był średni, średnia mieściła się w granicy stenu piątego. Średnia wartość uzyskana przez ankietowane pielęgniarki w kwestionariuszu IZZ (81,3 pkt) była niższa od standaryzacji dla kobiet (średnia arytmetyczna podana przez autora testu to $81,8 \mathrm{pkt}$ ). Mediana wyniosła $81 \mathrm{pkt}$ (SD = 13,95). Grupa kontrolna uzyskała istotnie niższy średni wynik od grupy badanej (77,1 pkt; $p<0,01)$. Ponadto wynik grupy kontrolnej był istotnie niższy od średniej podanej przez autora testu $(p<0,01)$. Wyniki uzyskane w kwestionariusz IZZ z podziałem na kategorie zachowań zdrowotnych przedstawione zgodnie z zaleceniami autora kwestionariusza jako średnia punktacja na pytanie zostały zestawione w tabeli 3 . Nie znaleziono związku pomiędzy prozdrowotnością stylu życia ankietowanych pielęgniarek a wykształceniem własnym $(p=0,23)$, wykształceniem matki ( $p=0,59)$, wykształceniem ojca $(p=0,82)$, a także miejscem zamieszkania $(p=0,96)$.

Najważniejszą analizą było poszukiwanie zależności stylu życia od wyników ankiety z wiedzy z zakresu chorób nowotworowych. Stwierdzono różnicę statystycznie znamienną pomiędzy stylem życia ankietowanych a posiadaną wiedzą z zakresu chorób nowotworowych $(p<0,01)$. Bardziej prozdrowotny styl życia charakteryzował pielęgniarki, które posiadały wyższą wiedzę z zakresu chorób nowotworowych. We wszystkich kategoriach Inwentarza Zachowań Zdrowotnych wyższa wiedza onkologiczna predysponowała do bardziej prozdrowotnego wyniku, a w żadnej z kategorii nie uzyskano większego wpływu niż w pozostałych.

\section{Omówienie wyników i dyskusja}

Podstawową hipotezą podjętego badania było założenie, że posiadanie odpowiedniej wiedzy na temat chorób nowotworowych będzie warunkować gotowość do zmiany stylu życia na bardziej prozdrowotny zarówno u siebie, jak i u objętych opieką pacjentów. Widoczne 
jest zapotrzebowanie na edukację w różnych grupach społecznych, a istotne znaczenie w tym procesie przypisać należy pielęgniarkom w ramach doradztwa zdrowotnego, które powinno stać się priorytetem w systemie ochrony zdrowia. Dlatego tym bardziej pielęgniarki powinny posiadać wiedzę na ponadprzeciętnym poziomie, a poziom wiedzy pielęgniarek na temat chorób nowotworowych wymaga ciągłego aktualizowania [6].

Po pierwsze, uzyskane wyniki badań - choć przeprowadzono je na stosunkowo małej grupie pielęgniarek pracującej na obszarze jednego województwa - dowodzą, że ogólna wiedza badanych pielęgniarek środowiskowych dotycząca chorób nowotworowych okazała się niewielka, a jejpoziom dość równomierny. Całości obrazu wiedzy ankietowanych pielęgniarek dopełnia niewiedza o częstości zachorowań i zgonów z powodu nowotworów. Nowotwory uznawane były w ankiecie najczęściej za rzadką przyczynę zachorowań i zgonów, co stoi w sprzeczności z danymi epidemiologicznymi. Dodatkowo w polskich realiach większość osób chorujących na nowotwory spędza terminalny okres choroby w domach, co związane jest z niewielką dostępnością hospicjów stacjonarnych.

Po drugie, wyniki badania pozwalają na lepszy wgląd w ocenę wiedzy dotyczącej wpływu czynników zewnętrznych na rozwój nowotworów. Należy podkreślić, że wiedza dotycząca wpływu stylu życia na zachorowania na nowotwory była statystycznie istotnie wyższa od wiedzy dotyczącej podstawowych pojęć z zakresu chorób nowotworowych i programów profilaktyki chorób nowotworowych. Przyczyny tej różnicy nie są do końca jasne. Może to być zasługa wiedzy przekazywanej poprzez edukację zawodową lub a może przede wszystkim - wynikać z prowadzenia, szczególnie w ostatnich latach, dość szeroko zakrojonych akcji medialnych nakłaniających do prozdrowotnego stylu życia, finansowanych najczęściej ze środków Unii Europejskiej. Dyskusja dotycząca wprowadzenia zakazu palenia w miejscach publicznych w krajach Unii Europejskiej, w tym i w Polsce, mogła również przyczynić się do wzrostu świadomości o wpływie palenia na rozwój niektórych nowotworów. Ankietowane pielęgniarki dość jednoznacznie uznawały palenie papierosów za szkodliwe, jednak już palenie bierne za szkodliwe uznawały rzadziej, chociaż świadomość w tym zakresie wydaje się pozostawać duża. Interesujące jest, że ankietowane rzadziej w porównaniu do palenia papierosów za szkodliwe uznawały nadmierne spożywanie alkoholu (odpowiednio: 3,44 i 2,85 pkt), zaś podobnie do tego ostatniego oceniały ryzyko związane z otyłością (2,70 pkt). Wysoko również oceniały ryzyko związane z nadmiernym opalaniem (3,18 pkt). Odpowiedzi te wpisują się w panujące w Polsce społeczne przyzwolenie na spoży- wanie alkoholu i uznawanie go za mniej szkodliwy nałóg niż nikotynizm. Cieszy wynik, że większość ankietowanych uznała nadmierne opalanie za zachowanie zwiększające ryzyko zachorowania na nowotwory, co prawdopodobnie wynika z upowszechniania wiedzy na temat zasad ochrony przed promieniowaniem słonecznym i właściwego stosowania preparatów kosmetycznych o działaniu promieniochronnym. Wiedza ta w ostatnich latach była promowana w środkach masowego przekazu przez firmy produkujące kosmetyki promieniochronne, co pozwala przypuszczać, że właściwie prowadzona i zakrojona na szeroką skalę kampania medialna jest w stanie podnieść wiedzę społeczeństwa w promowanym zakresie. Podobne wnioski można wyciągnąć co do społecznie akceptowanej walki z otyłością, a jej rezultaty powinny być bardziej widoczne za kilka lat, zważywszy na obecne promowanie środków wspomagających odchudzanie i produktów spożywczych typu „light” oraz rosnące zainteresowanie ćwiczeniami fizycznymi i zabiegami medycznymi, np. bariatrycznymi.

Próba oceny, w której dziedzinie są największe braki wiedzy onkologicznej, przyniosła rozczarowanie. Najbardziej martwi poziom wiedzy w zakresie prowadzonych przez Narodowy Fundusz Zdrowia programach badań profilaktycznych. Centrum Badania Opinii Społecznej w 2007 roku przeanalizowało przyczyny niepoddawania się badaniom profilaktycznym. We wnioskach napisano, że ludzie w Polsce nie poddają się badaniom profilaktycznym przede wszystkim dlatego, że uważają się za zdrowych i nie mają na to czasu [7]. Ważną przyczyną okazały się także być lęk i obawa o wynik. Nasze badanie udowadnia jednak także, że przyczyną może być brak dostatecznej wiedzy na temat prowadzonych programów profilaktyki nowotworów w Polsce, nawet wśród pracowników służby zdrowia odgrywających pierwszoplanową rolę w kontakcie z chorym oraz w szeroko pojętej profilaktyce.

Choć w naszym badaniu widać tendencję, że wiedza o chorobach nowotworowych rośnie wraz z wykształceniem ankietowanych pielęgniarek i ich wiekiem, jednak nie był to trend istotny statystycznie. Najbardziej niepokojący niski poziom wiedzy przedstawiały pielęgniarki młode, co wydaje się potwierdzać niektóre głosy opinii publicznej o zaniżającym się poziomie edukacji. Nikła wiedza onkologiczna pielęgniarek młodych i jej wzrost wraz z wiekiem może także pozwalać na jeszcze jeden wniosek: pielęgniarki nie wynoszą dostatecznej wiedzy onkologicznej ze szkoły, ale nabywają ją wraz z doświadczeniem zawodowym. W opinii autora grupy są jednak zbyt mało liczne, by wyciągać ostateczne wnioski.

Podsumowując, prowadzone badania mają zazwyczaj charakter reprezentatywny, tzn. na podstawie próby chcemy uzyskać, z określonym prawdopodo- 
bieństwem popełnienia błędu, możliwość wnioskowania o generalnej sytuacji w całej zbiorowości będącej przedmiotem zainteresowania. Co prawda zbadaliśmy nieliczną grupę, ale jeżeli nasze wnioski potwierdziłyby się w badaniu na większej populacji, to wydaje się, że tylko właściwie przeprowadzony program edukacji w zakresie chorób nowotworowych, obejmujący wszystkie pielęgniarki, przed wyborem zakresu dalszej edukacji mógłby poprawić zaistniałą sytuację. W opinii autora program taki winien być ciągły i w swoim przebiegu uwzględniać specyfikę pracy pielęgniarek środowiskowych. Ważnym osiągnięciem naszej pracy po raz kolejny pozostaje stwierdzenie znamiennej statystycznie różnicy pomiędzy stylem życia ankietowanych a posiadaną wiedzą z zakresu chorób nowotworowych [8]. Bardziej prozdrowotny styl życia charakteryzował pielęgniarki, które posiadały wyższą wiedzę z zakresu chorób nowotworowych. Dowodzi to związku między stanem wiedzy dotyczącym chorób nowotworowych a gotowością przyjęcia postaw i zachowań prozdrowotnych. Wobec wykazania generalnie średniej wiedzy dotyczącej chorób nowotworowych wśród pielęgniarek nasza praca podkreśla znaczenie rozwijania edukacji prozdrowotnej w Polsce, nawet wśród personelu służby zdrowia. Takie wychowanie zdrowotne nie tylko powinno obejmować przekazywanie wiedzy o tym, co jest korzystne lub szkodliwe dla zdrowia, lecz przede wszystkim - rozwijać umiejętności, które pomagają skutecznie wykorzystać nabytą wiedzę.

\section{Piśmiennictwo}

1. Pasz-Walczak G. Zapobieganie. W: Kordek R (red). Onkologia. Podręcznik dla studentów i lekarzy. Gdańsk: Via Medica; 2007. 52-57.

2. Zakres kompetencji pielęgniarki i położnej POZ. NFZ. Zasady udzielania świadczeń zdrowotnych.

3. Profilaktyka raka piersi, www.profilaktykaraka.coi.waw.pl/cokpiersi/mammo/ (data dostępu: 11.05.2011).

4. Profilaktyka raka szyjki macicy, ftp://ftp.nfz-lodz.pl_OW.pdf (data dostępu: 11.05.2011).

5. Juczyński Z. Narzędzia pomiaru w promocji i psychologii zdrowia. Warszawa: PTS; 2009.

6. Smoleń E, Dobrowolska B. Wiedza pielęgniarek województwa lubelskiego i podkarpackiego w zakresie czynników ryzyka nowotworów piersi. Med Ogólna. 2014; 20: 6-11.

7. Postawy i opinie młodzieży na temat chorób nowotworowych. Warszawa: CBOS; 2007.

8. Adamowicz K, Zalewska M, Majkowicz M, Zaucha JM. Evaluation of the Impact of Different Types of Health Education on the Adoption and Preservation of Prohealth Attitudes in Preventing Cancer in Juveniles Younger than 18 Years. J Cancer Educ. 2015; 30: 432-438.

Artykuł przyjęty do redakcji: 20.08.2016

Artykuł przyjęty do publikacji: 09.12.2016

Źródło finansowania: Praca nie jest finansowana z żadnego źródła. Konflikt interesów: Autor deklaruje brak konfliktu interesów.

Adres do korespondencji:

Krzysztof Adamowicz

ul. Alojzego Jagalskiego 10

84-200 Wejherowo

tel.: 585727828

e-mail: krzys.adamowicz@gmail.com

Szpital Specjalistyczny w Wejherowie 